\title{
Study on Fatigue Life of Plow Bit under Different Planning Parameters
}

\author{
Q. Zhang, ${ }^{\text {a,b,c }}$ M. J. Xu, ${ }^{a}$ and N. Hu \\ ${ }^{a}$ College of Mechanical Engineering, Liaoning Technical University, Fuxin, China \\ b State Key Laboratory of Structural Analysis for Industrial Equipment, Dalian University of \\ Technology, Dalian, China \\ ${ }^{c}$ China National Coal Mining Equipment Co., Ltd, Beijing, China
}

УДК 539.4

\section{Исследование усталостной долговечности бурового долота с различными параметрами проектирования}

\author{
к. Жанг ${ }^{\mathrm{a}, \overline{0}, \mathrm{~s}}$, М. Ж. Ксу ${ }^{\mathrm{a}}$, Н. $\mathbf{X y}^{\mathrm{a}}$ \\ а Факультет машиностроения, Ляонинский технический университет, Фуксин, Китай \\ б Государственная лаборатория структурного анализа для промышленного оборудования, \\ Далянский технологический университет, Далян, Китай

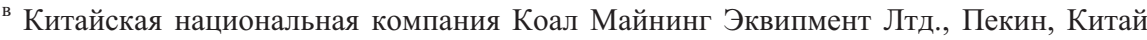 \\ С иелью исследования усталостной долговечности бурового долота с различными парамет- \\ рами технологического проектирования проведено моделирование процесса подрезки уголь- \\ ного пласта с помощью долота на основе твердотельной модели. Изменение напряжения $в$ \\ соединении между лопаткой и твердосплавной головкой получили путем моделирования \\ проиесса проектирования при различных параметрах разработки слабого соединения (угол \\ подрезки, толщина и шаг долота). Усталостную долговечность долота прогнозировали с \\ помощью усовершенствованного метода дождевого потока и правила Майнера. Согласно \\ данным испытаний на усталость значения амплитуды напряжений и накопления повреж- \\ дений за один ход являются наименьшими при угле подрезки $80^{\circ}$, при этом количество рабочих \\ ходов и часов поврежденного долота достигает максимума. Чем толще долото, тем больше \\ его сопротивление и тем значительнее повреждение. Кроме того, чем меньше шаг долота, \\ тем проще его спроектировать и тем меньше повреждение. Результаты испьтаний соот- \\ ветствуют данным теоретического анализа.
}

Ключевые слова: долото, усталостная долговечность, усовершенствованный метод дождевого потока, шаг долота, толщина долота, угол подрезки.

Introduction. Coal planer cuts the coal rock by continuous cyclical impact of chain haulage. Figure 1 shows the plow chart, whose cutting coal tool is the plow bit, However, the plow is easily damaged in the form of the weld fracture and carbide head shedding, etc, which directly affects the work reliability and coal production efficiency [1-9]. To figure out the flow damaged causes of the sliding coal planner, effective measures have been taken to reduce energy consumption and loss of plow by studying the loading behavior of the working plow. Figure 2 depicts the plow bit physical map. Due to the environmental conditions, coal properties and the interaction between coal and plow, computer numerical simulation is combined with lab experiments to investigate the strength and fatigue life of plow bit under different planning parameters, which is of significance for improving the work reliability of the plow. 


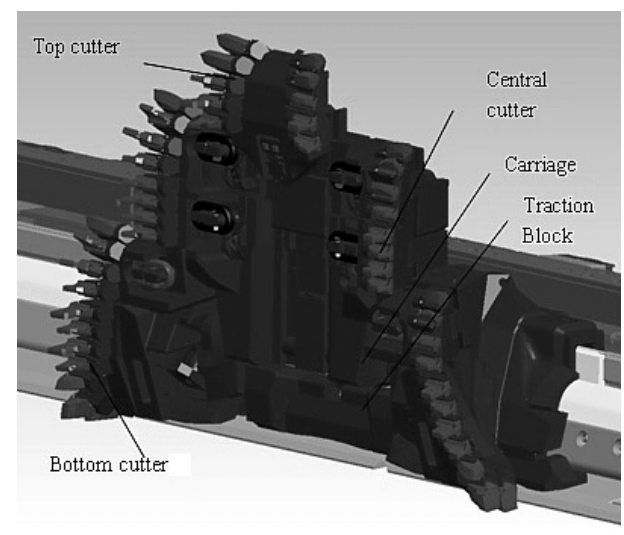

Fig. 1. Plow chart.

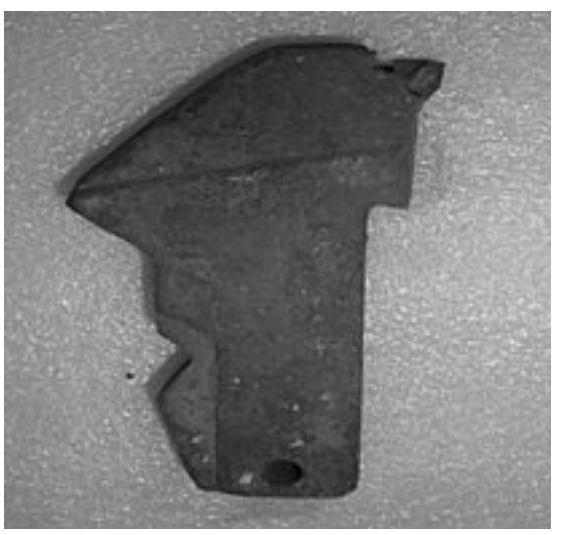

Fig. 2. Plow bit physical map.

In order to explore the stress condition of the working plow, its strength and fatigue life, a solid model for the plow bit is constructed using the material model of a flexible body (MAT-PLASTIC-KINEMATIC). In addition, a constitutive model for the coal is established based on the non-grid smoothed particle hydrodynamics (SPH). By selecting the joint between the blade and carbide head as the weak location, the process of plow bit cutting a coal seam is simulated by the Hyper Mesh and LS-DYNA, whose results are analyzed in a combination with the test results. This paper provides a new method to study the working conditions of a coal seam-cutting plow pit, as well as the strength and fatigue life of a plow bit.

\section{Establishment of the Plow Cutting Coal Seam.}

1.1. Plow Bit Model. As the plow bit is complex in structure and subject to three-way random loading in actual work, Pro/E software is used for modeling, and SD Solid 164 unit type and flexible body material model is applied for the finite element simulation. Figure 3 shows the plow meshing with 57,913 units and 11,696 nodes, while Fig. 4 illustrates the finite element model of plow bit and coal seam. Blade materials and their mechanical properties are tabulated in Table 1.

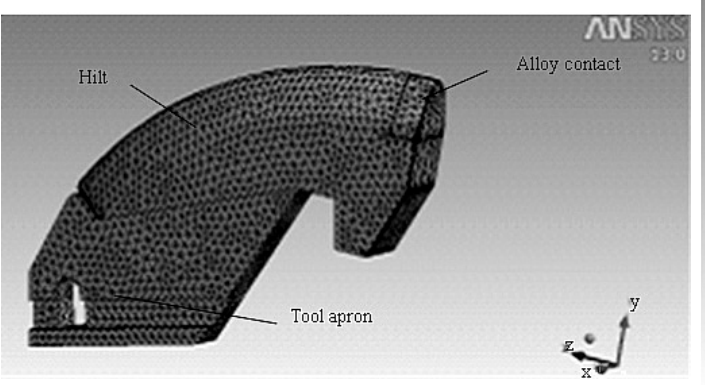

Fig. 3. Model of plow bit.

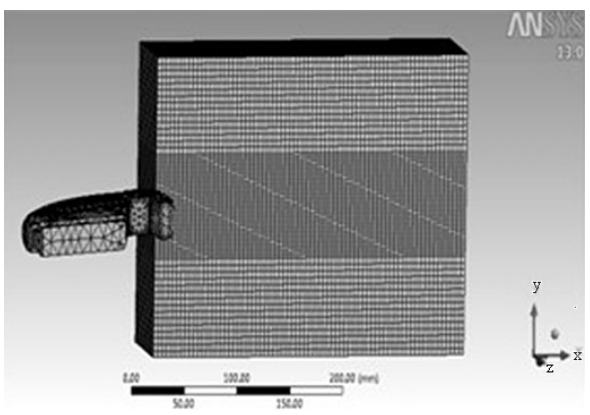

Fig. 4. Finite element model of plow bit and coal seam.

1.2. Constitutive Model of Coal Seam. The accuracy of the finite element analysis strongly depends on the material and the material parameters used in the model. Modeling by SPH method can simply and accurately achieve complex constitutive behavior, such as simulating structural disintegration, fragmentation and cratering, as well as the spall and brittle fracture of solids, etc. In this method, the kernel estimation of any macroparameter 
$\mathrm{T}$ a b 1 e 1

Mechanical Characteristics of Investigated Materials

\begin{tabular}{|c|c|c|c|c|}
\hline Blade material & $\begin{array}{c}\text { Elastic modulus } \\
E, \text { MPa }\end{array}$ & $\begin{array}{c}\text { Poisson's ratio } \\
v\end{array}$ & $\begin{array}{c}\text { Yield strength } \\
\sigma_{s}, \mathrm{MPa}\end{array}$ & $\begin{array}{c}\text { Density } \\
\rho, \mathrm{g} / \mathrm{cm}^{3}\end{array}$ \\
\hline $40 \mathrm{Cr}$ & $2.10 \cdot 10^{5}$ & 0.25 & 980 & 8.3 \\
\hline YG8 & $5.40 \cdot 10^{5}$ & 0.30 & 1890 & 14.5 \\
\hline HL105 & $3.78 \cdot 10^{5}$ & 0.28 & 330 & 1.3 \\
\hline
\end{tabular}

(e.g., density, pressure, temperature) in one spatial point ( $r$ ), can be obtained by the integral of $f(r)$ in $\Omega$ domain

$$
\langle f(x)\rangle=\int_{\Omega} f\left(r^{\prime}\right) W\left(r-r^{\prime} ; h\right) d r^{\prime},
$$

where $W\left(r-r^{\prime} ; h\right)$ is a kernel function and $h$ is the smoothing length.

Generally, $\langle f(x)\rangle$ is called a kernel estimate of $f(r)$. Let $f_{j}$ be the value of particle $j$ in $f(r)$, Eq. (1) can be written in the form of particle summation

$$
f(x)=\sum_{j=1}^{N} \frac{m_{j} f_{j}}{\rho_{j} h} W_{i j}\left(\frac{\left|r_{i}-r_{j}\right|}{h}\right),
$$

where $N$ is the total number of particles in computational domain, $m_{j}, f_{j}$, and $\rho_{j}$ are the quality, the parameter to be calculated, and the density of particle $j$ in the spatial point $(r)$, respectively. Similarly, the kernel estimation of the first derivative of $f(r)$ in particle $i$ can be denoted by

$$
\frac{\partial f_{i}}{\partial x_{i}^{x}}=\sum_{j=1}^{N} \frac{m_{j} f_{j}}{\rho_{j} h} W_{i j}^{\prime} \frac{x_{i}^{x}-x_{j}^{x}}{\left|r_{i}-r_{j}\right|} \quad(s=x, y, z) .
$$

The most common smooth kernel used in SPH is the cubic b-spline, defined as

$$
W_{i j}= \begin{cases}\left(1-1.5 \phi^{2}+0.75 \phi^{3}\right) / \beta & (0 \leq \phi<1), \\ 0.25(2-\phi)^{3} / \beta & (1 \leq \phi<2), \\ 0 & (\phi \geq 2),\end{cases}
$$

where $\phi=\left|r_{i}-r_{j}\right| / h$, and $\beta$ is selected as $\beta=1.5 h, \beta=0.7 \pi h^{2}$, and $\beta=\pi h^{3}$ corresponding to the one-, two-, and three-dimensional problems, respectively.

Due to the brittle fracture of a coal-cutting plow bit, model 13\# with brittle cracking material is chosen in LS-DYNA as the elastic-plastic material fracture model (MATISOTROPIC-ELASTIC-FAILURE), where the shear modulus of $1190 \mathrm{MPa}$, the bulk modulus of $2580 \mathrm{MPa}$, the plastic reinforcement modulus of $100 \mathrm{MPa}$, Poisson's ratio of 0.3 , and plastic fracture strain of 0.06 .

2. Fatigue Life Prediction of Plow Bit for Different Planning Parameters.

2.1. Impact of Cutting Angle on Fatigue Life. Let the planning speed $v=2.5 \mathrm{~m} / \mathrm{s}$, planning depth $h=20 \mathrm{~mm}$, and plow thickness $b=30 \mathrm{~mm}$. The cutting angle is obtained by simulating the model using LS-DYNA. The changing curves of the shear stress with the 
cutting angle of 70,80 , and $90^{\circ}$ are extracted for statistical treatment. Let stress of $i$ be $x$, then mean value $\bar{x}$, mean square deviation $S$, and variation coefficient $t$ in the whole planning process can be calculated as

$$
\begin{gathered}
\bar{x}=\frac{1}{n} \sum_{i=1}^{n} x_{i}, \\
S=\left(\frac{1}{n} \sum_{i=1}^{n}\left(x_{i}-\bar{x}\right)^{2}\right)^{1 / 2}, \\
t=\frac{S}{\bar{x}} .
\end{gathered}
$$

The statistical result of the stress at the joint between the blade and carbide head, which was calculated via the MATLAB program is shown in Table 2 the fatigue life of the plow bit is predicted using the improved rain-flow method and Miner linear accumulated fatigue damage model. The statistical result is expressed by stress amplitude and vector quantity, isofar as the rain-flow counting method involves two parameters. However, the MATLAB program is used to improve the rain-flow program, thus avoiding the leaking points caused by improper docking. The stress amplitudes of a stroke are shown in Fig. 5 with working face length being $100 \mathrm{~m}$ at the cutting angle of 70,80 , and $90^{\circ}$, respectively.

T a b 1 e 2

Statistical Result of the Stress at the Joint between the Blade and Carbide Head

\begin{tabular}{|c|c|c|c||}
\hline \multirow{2}{*}{ Parameter } & \multicolumn{3}{|c|}{ Cutting angle $\beta$, deg } \\
\cline { 2 - 4 } & 70 & 80 & 90 \\
\hline$\sigma_{\max }, \mathrm{MPa}$ & 59.1656 & 49.0864 & 59.973 \\
\hline$\sigma_{\min }, \mathrm{MPa}$ & 1.7760 & 1.4730 & 1.793 \\
\hline$\sigma_{\text {mean }}, \mathrm{MPa}$ & 51.4163 & 40.0650 & 56.434 \\
\hline Mean-square deviation $S$ & 31.924 & 20.912 & 35.841 \\
\hline Variation coefficient $t$ & 0.627 & 0.612 & 0.782 \\
\hline
\end{tabular}

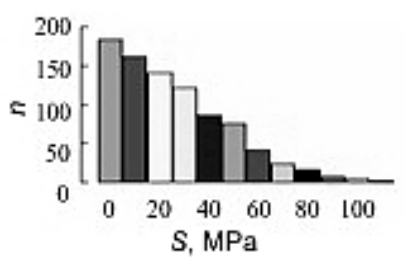

a

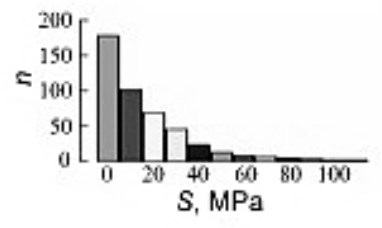

b

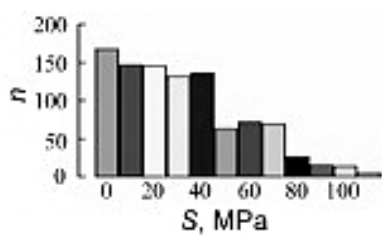

$\mathrm{c}$

Fig. 5. Stress amplitude circulation chart of plow bit for different cutting angles $\beta$ : (a) $\beta=70^{\circ}$; (b) $\beta=80^{\circ}$; (c) $\beta=90^{\circ}$.

The power function of $S-N$ curve is used to predict the fatigue life for different cutting angles, defined as $N S^{m}=C$, where $N$ is the cycle index of fatigue failure at stress 
level $S$, where $m$ and $C$ are the material constants which, according to studies [12, 13], are set as $m=7.31$ and $C=1.422917 \cdot 10^{19}$, respectively. Based on the Miner linear accumulated fatigue damage, the accumulated damage $D$ and the fatigue life of the plow bit can be calculated under the random loading, with damage occurring at $D=1$,

$$
D=\sum_{i=1}^{r} \frac{n_{i}}{N_{i}}=1,
$$

where $n_{i}$ is the cycle number at a certain stress level and $N_{i}$ is fatigue life at the stress.

Let the working time of coal planner be $18 \mathrm{~h}$ per day, total work time of a damaged plow bit is shown in Table 3 .

$\mathrm{T}$ a b 1 e 3

Cumulative Damage and Fatigue Life of Plow Bit

\begin{tabular}{||l|c|c|c||}
\hline \multirow{2}{*}{ Parameter } & \multicolumn{3}{|c||}{ Cutting angle $\beta$, deg } \\
\cline { 2 - 4 } & 70 & 80 & 90 \\
\hline Cumulative damage of a stroke & $2.84551 \cdot 10^{-5}$ & $2.422917 \cdot 10^{-5}$ & $3.73459 \cdot 10^{-5}$ \\
\hline $\begin{array}{l}\text { Number of working strokes } \\
\text { with a damaged plow bit }\end{array}$ & $3.5591 \cdot 10^{4}$ & $3.9687 \cdot 10^{4}$ & $2.7645 \cdot 10^{4}$ \\
\hline $\begin{array}{l}\text { Number of working hours of plow } \\
\text { with a damaged plow bit }\end{array}$ & 47.6 & 52.8 & 34.5 \\
\hline
\end{tabular}

$\mathrm{T}$ a b 1 e 4

Statistical Results on Stress at the Joint between the Blade and Carbide Head

\begin{tabular}{|c|c|c|c||}
\hline \multirow{2}{*}{ Parameter } & \multicolumn{3}{|c||}{ Plane width $b_{p}, \mathrm{~mm}$} \\
\cline { 2 - 4 } & 25 & 30 & 40 \\
\hline$\sigma_{\max }, \mathrm{MPa}$ & 38.8978 & 49.0864 & 58.8924 \\
\hline$\sigma_{\min }, \mathrm{MPa}$ & 0.7780 & 1.4730 & 3.8890 \\
\hline$\sigma_{\text {mean }}, \mathrm{MPa}$ & 31.2416 & 40.0650 & 46.2350 \\
\hline Mean-square deviation $S$ & 19.568 & 20.912 & 35.841 \\
\hline Variation coefficient $t$ & 0.5270 & 0.6120 & 0.7172 \\
\hline \hline
\end{tabular}

$\mathrm{T}$ a b 1 e 5

Cumulative Damage and Fatigue Life of Plow Bit

\begin{tabular}{||l|c|c|c||}
\hline \multirow{2}{*}{ Parameter } & \multicolumn{3}{c||}{ Plane width $b_{p}, \mathrm{~mm}$} \\
\cline { 2 - 4 } & 25 & 30 & 40 \\
\hline Cumulative damage of a stroke & $1.9153 \cdot 10^{-5}$ & $2.422917 \cdot 10^{-5}$ & $3.4531 \cdot 10^{-5}$ \\
\hline $\begin{array}{l}\text { Number of working strokes with a damaged } \\
\text { plow bit }\end{array}$ & $4.0125 \cdot 10^{4}$ & $3.9687 \cdot 10^{4}$ & $2.8102 \cdot 10^{4}$ \\
\hline $\begin{array}{l}\text { Number of working hours of plow } \\
\text { with a damaged plow bit }\end{array}$ & 53.40 & 52.80 & 35.12 \\
\hline
\end{tabular}


T a b 1 e 6

Statistical Results on Stress at the Joint between the Blade and Carbide Head

\begin{tabular}{|c|c|c|c||}
\hline \multirow{2}{*}{ Parameter } & \multicolumn{3}{|c||}{ Plane distance $S_{p}, \mathrm{~mm}$} \\
\cline { 2 - 4 } & 30 & 40 & 50 \\
\hline$\sigma_{\max }, \mathrm{MPa}$ & 45.1253 & 49.0864 & 62.583 \\
\hline$\sigma_{\min }, \mathrm{MPa}$ & 1.358 & 1.473 & 3.478 \\
\hline$\sigma_{\text {mean }}, \mathrm{MPa}$ & 38.469 & 40.065 & 45.987 \\
\hline Mean-square deviation $S$ & 15.987 & 20.912 & 23.120 \\
\hline Variation coefficient $t$ & 0.589 & 0.612 & 0.788 \\
\hline
\end{tabular}

$\mathrm{T}$ a b 1 e 7

Cumulative Damage and Fatigue Life of Plow Bit

\begin{tabular}{||l|c|c|c||}
\hline \multirow{2}{*}{ Parameter } & \multicolumn{2}{c||}{ Plane distance $S_{p}, \mathrm{~mm}$} \\
\cline { 2 - 4 } & 30 & 40 & 50 \\
\hline Cumulative damage of a stroke & $2.0455 \cdot 10^{-5}$ & $2.422917 \cdot 10^{-5}$ & $4.2369 \cdot 10^{-5}$ \\
\hline $\begin{array}{l}\text { Number of working strokes with a damaged } \\
\text { plow bit }\end{array}$ & $4.2519 \cdot 10^{4}$ & $3.9687 \cdot 10^{4}$ & $2.3645 \cdot 10^{4}$ \\
\hline $\begin{array}{l}\text { Number of working hours of plow } \\
\text { before damage }\end{array}$ & 54.60 & 52.80 & 30.21 \\
\hline
\end{tabular}

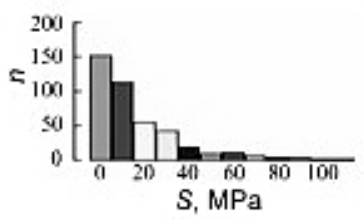

a

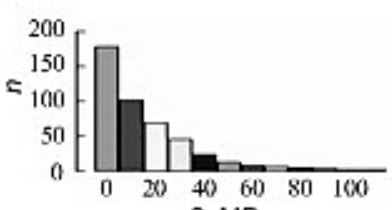

$\mathrm{S}, \mathrm{MPa}$

$\mathrm{b}$

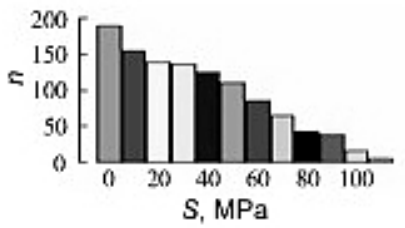

$\mathrm{c}$

Fig. 6. Stress amplitude circulation chart of plow bit for different plane width values $b_{p}$ : (a) $b_{p}=$ $=25 \mathrm{~mm}$; (b) $b_{p}=30 \mathrm{~mm}$; (c) $b_{p}=40 \mathrm{~mm}$.

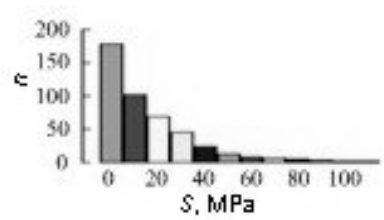

a

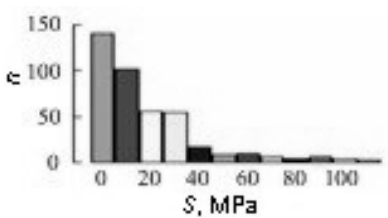

b

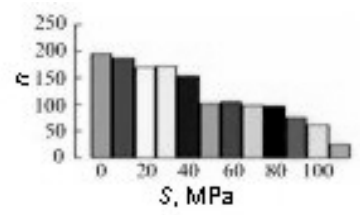

c

Fig. 7. Stress amplitude circulation chart of plow bit for different values of the plane distance $S_{p}$ : (a) $S_{p}=30 \mathrm{~mm}$; (b) $S_{p}=40 \mathrm{~mm}$; (c) $S_{p}=50 \mathrm{~mm}$.

2.2. Impact of Plane Width on Fatigue Life. Let the planning speed be $v=2.5 \mathrm{~m} / \mathrm{s}$, planning depth $h=20 \mathrm{~mm}$, and cutting angle $\beta=80^{\circ}$. Plane width $b_{p}$ is obtained as 25 , 30 , and $40 \mathrm{~mm}$ by simulating the model using LS-DYNA. After statistical processing of the stress curve according to the method described in Section 2.1, the result is obtained via the MATLAB program, as is shown in Table 4. Using the improved rain-flow method and the 
Miner linear accumulated fatigue damage model, the stress amplitude of the blow per one stroke is shown in Fig. 6 and tabulated in Table 5 for the working face length of $100 \mathrm{~m}$, after obtaining the three plane width values by the processing of the LS-DYNA-simulated stress curve.

2.3. Impact of Plane Distance on the Fatigue Life. Let the planning speed $v=2.5 \mathrm{~m} / \mathrm{s}$, planning depth $h=20 \mathrm{~mm}$, cutting angle $\beta=80^{\circ}$, and plow thickness $b_{p}=30 \mathrm{~mm}$. By the LS-DYNA model simulation, the plane distances $S_{p}$ equal to 30,40 , and $50 \mathrm{~mm}$, respectively, were obtained. Using the statistical method described in Section 2.1 and the MATLAB program, the statistical results on the stress values at the joint between the blade and carbide head were obtained, which are tabulated in Table 6 and depicted in Fig. 7.

Using the improved rain-flow method and the Miner linear accumulated fatigue damage model, the stress amplitude of the blow per one stroke was obtaine with the working face length of $100 \mathrm{~m}$, after obtaining the three plane distance values by the processing of the LS-DYNA stress curve, as is shown in Fig. 7. Assuming the working time of coal planner to be $18 \mathrm{~h}$ per day, the total work time of the plow with a damaged plow bit is given in Table 7.

3. Experimental Study for Different Planning Parameters. Due to the limit conditions, the experiment adopts the plot thickness as $25 \mathrm{~mm}$, with the physical property parameters given in Table 8.

T a b 1 e 8

Parameters of Physical Properties of Specimens

\begin{tabular}{|c|c|c|c|c|c|c|c|c|c||}
\hline $\begin{array}{c}\text { Speci- } \\
\text { men } \\
\text { type }\end{array}$ & $\begin{array}{c}\text { Compres- } \\
\text { sive } \\
\text { strength } \\
(\mathrm{MPa})\end{array}$ & $\begin{array}{c}\text { Tensile } \\
\text { strength } \\
(\mathrm{MPa})\end{array}$ & $\begin{array}{c}\text { Shear } \\
\text { strength } \\
(\mathrm{MPa})\end{array}$ & $\begin{array}{c}\text { Cohesio } \\
\mathrm{n} \\
(\mathrm{MPa})\end{array}$ & $\begin{array}{c}\text { Friction } \\
\text { angle } \\
(\mathrm{deg})\end{array}$ & $\begin{array}{c}\text { Friction } \\
\text { coefficie } \\
\mathrm{nt}\end{array}$ & $\begin{array}{c}\text { Static } \\
\text { elastic } \\
\text { modulus } \\
(\mathrm{MPa})\end{array}$ & $\begin{array}{c}\text { Pois- } \\
\text { son's } \\
\text { ratio }\end{array}$ & $\begin{array}{c}\text { Bulk } \\
\text { density } \\
\left(\mathrm{kg} / \mathrm{m}^{3}\right)\end{array}$ \\
\hline $\mathrm{f} 0.4$ & 40 & 4.015 & 16.54 & 12.1 & 65.1 & 2.6 & $1.023 \cdot 10^{4}$ & 0.225 & 2004 \\
\hline $\mathrm{f} 0.8$ & 80 & 4.121 & 18.31 & 15.9 & 70.2 & 2.8 & $5.826 \cdot 10^{4}$ & 0.275 & 2112 \\
\hline $\mathrm{f} 1.2$ & 120 & 6.213 & 19.72 & 16.3 & 72.5 & 3.2 & $7.541 \cdot 10^{4}$ & 0.312 & 2480 \\
\hline
\end{tabular}

T a b 1 e 9

Design of Orthogonal Experiment Array Experimental Design

\begin{tabular}{||c|c|c|c|c|c|c|c|c|c||}
\hline \hline Test number & A & B & C & D & E & F & G & H & I \\
\hline $\mathrm{a}$ & 1 & 2 & 3 & 1 & 2 & 3 & 1 & 2 & 3 \\
\hline $\mathrm{b}$ & 1 & 1 & 1 & 2 & 2 & 2 & 3 & 3 & 3 \\
\hline $\mathrm{c}$ & 1 & 2 & 3 & 2 & 3 & 1 & 3 & 1 & 2 \\
\hline
\end{tabular}

The orthogonal experiment can be used to simulate the impact of error factors and analyze the data obtained by fewer experiments, thus achieving a satisfactory result.

4. Orthogonal Factors' Table. The orthogonal experiment is used through L9 (34) without considering the interaction, as shown in Table 9, where $A$ is the cutting angle, $B$ is the plow thickness, and $C$ is the plow spacing.

Figure 8 presents the overview of coal or rock specimens used, and Fig. 9 illustrates the test analysis system. The number of working strokes and the total working time are obtained from the experiment, as is shown in Fig. 10. 


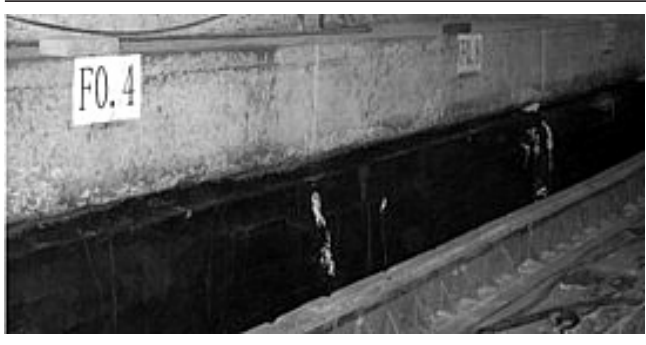

Fig. 8. A coal or rock specimen.

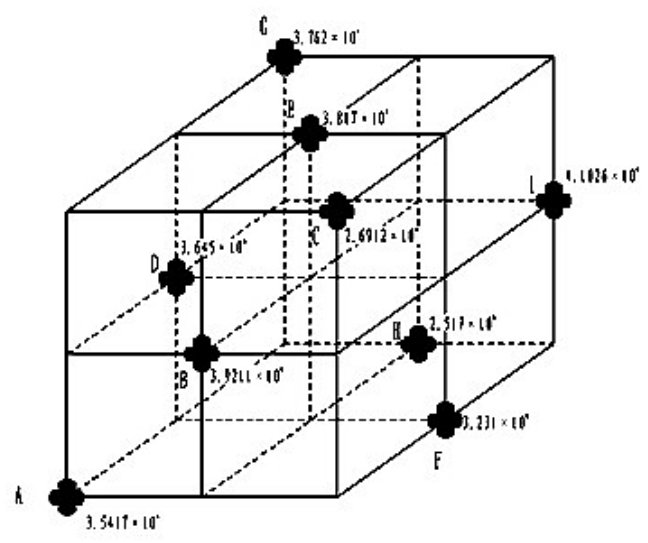

a

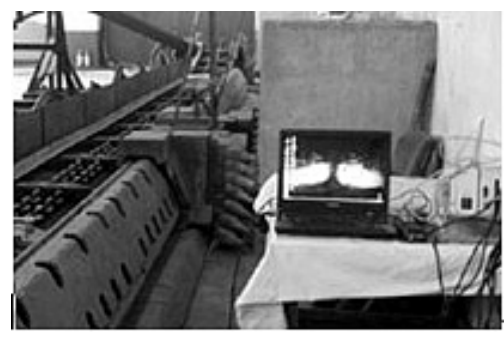

Fig. 9. Test analysis system.

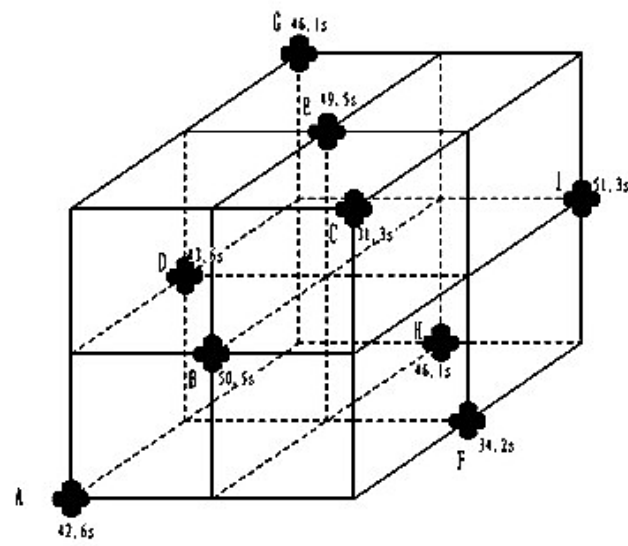

b

Fig. 10. Cumulative damage (a) and fatigue life (b) of the plow bit test.

There are two groups in the orthogonal experiment (planning cutting angle $\beta=80^{\circ}$, plow thickness $b_{p}=25 \mathrm{~mm}$, and plow spacing $S_{p}=40 \mathrm{~mm}$ ), while the results obtained are lower than the theoretical values, due to the impact of dynamic loading on the plow abrasion. The theoretical results generally agree with the test data.

\section{Conclusions}

1. A three-dimensional solid model of the plow pit and the finite element model of the coal are constructed, which provide some guidelines for simulating the coal-cutting plow bit and predicting the plow bit fatigue life.

2. According to the simulation results, the shear stress strongly depends on the cutting angle. The stress amplitude and accumulated damage per one stroke attain the minimal values at the cutting angle of $80^{\circ}$, whereas the number of working strokes and working hours reach the maximum values. The thicker is the plow bit, higher are the coal resistance and the plow bit damage. In addition, a smaller plow spacing results in higher planning ability and smaller damage.

3. The orthogonal experiment results show that the measured number of working stokes and working time of plow basically agree with the respective results of the theoretical analysis.

\section{Резюме}

Із метою дослідження довговічності від утомленості бурового долота 3 різними параметрами технологічного проектування проведено моделювання процесу підрізки 
вугільного пласта за допомогою долота на основі твердотільної моделі. Зміну напруження в з'єднанні між лопаткою і твердосплавною головкою отримали шляхом моделювання процесу проектування за різних параметрів розробки слабкого з'єднання (кут підрізки, товщина і крок долота). Довговічність від утомленості долота спрогнозували за допомогою удосконаленого методу дощового потоку і правила Майнера. Згідно з даними випробувань на утому значення амплітуди напружень і накопичення пошкоджень за один хід $є$ найменшими при куті підрізки $80^{\circ}$, при цьому кількість робочих ходів і годин пошкодженого долота сягає максимуму. Чим товще долото, тим більший його опір і тим значніше пошкодження. Окрім того, чим менший крок долота, тим простіше його спроектувати і тим менше пошкодження. Результати випробувань збігаються 3 даними теоретичного аналізу.

1. X. M. Kang, G. X. Li, and Y. H. Zhi, "To minimize energy consumption as the goal to optimize planning depth," Coal Mining Machin., 9, 42-44 (2004).

2. X. M. Kang, G. X. Li, and Y. H. Zhi, "To set off the conveyor cargo area even as the objective to optimize planning depth," Mining Machin., 33, No. 2, 14-16 (2005).

3. X. H. Li, X. Liu, and L. Li, "Dynamic simulation of sliding coal plow under different working conditions," J. China Coal Soc., 35, No. 7, 1202-1207 (2010).

4. Z. R. Wang, X. Y. Xiong, H. Zhang, et al., "Study on conical pick cutting using LS-DYN," J. Vibr. Measur. Diagn., 30, No. 2, 163-210 (2010).

5. Q. Zhang, Y. F. Fu, Q. S. Song, et al., "Parameter optimization of lowest energy consumption for plow based on artificial fish school algorithm," J. Guangxi Univ. (Natural Science Edition), 37, No. 2, 241-247 (2012).

6. X. H. Li, "Study of cutting performance for a flat pick," J. Liaoning Technol. Univ. (Natural Science), 19, No. 5, 526-529 (2000).

7. J. Walker and H. S. Yu, "Adaptive finite element analysis of cone penetration in clay," Acta Geotech., 1, No. 1, 43-57 (2006).

8. X. H. Li, Z. L. Huang, and Y. He, "Simulation research on cutting ability of MK 97-002 type plow bit," J. Fuzhou Univ. (Natural Science Edition), 40, No. 2, 222-226 (2012).

9. Y. M. Zhang, X. Z. Huang, and X. D. He, "Reliability-based robust design for kinematic accuracy of the planar linkage mechanism with arbitrary distribution parameters," Trans. Chinese Soc. Agricult. Machin., 39, No. 7, 139-143 (2008).

10. X. M. Kang, G. X. Li, and Y. H. Zhi, "Set off the conveyor cargo area even as the objective to optimize planning depth," Mining Machin., 33, No. 2, 14-16 (2005).

11. X. M. Kang and G. X. Li, "Single degree of freedom dynamic model of coal plough and its simulation," J. Vibr. Shock, 28, No. 2, 191-195 (2009). 